\title{
Focus on ART
}

\section{Derivation, growth and applications of human embryonic stem cells}

\author{
Miodrag Stojkovic, Majlinda Lako, Tom Strachan and Alison Murdoch ${ }^{1}$ \\ Institute of Human Genetics, University of Newcastle, Newcastle upon Tyne, NE1 3BZ, UK and ${ }^{1}$ Newcastle \\ Fertility Centre at Life, NHS, Newcastle upon Tyne, NE1 4EP, UK
}

Correspondence should be addressed to M Stojkovic; Email: miodrag.stojkovic@ncl.ac.uk

\begin{abstract}
Human embryonic stem (hES) cells are pluripotent cells derived from the inner cell mass cells of blastocysts with the potential to maintain an undifferentiated state indefinitely. Fully characterised hES cell lines express typical stem cell markers, possess high levels of telomerase activity, show normal karyotype and have the potential to differentiate into numerous cell types under in vitro and in vivo conditions. Therefore, hES cells are potentially valuable for the development of cell transplantation therapies for the treatment of various human diseases. However, there are a number of factors which may limit the medical application of hES cells: (a) continuous culture of hES cells in an undifferentiated state requires the presence of feeder layers and animal-based ingredients which incurs a risk of cross-transfer of pathogens; (b) hES cells demonstrate high genomic instability and non-predictable differentiation after long-term growth; and (c) differentiated hES cells express molecules which could cause immune rejection. In this review we summarise recent progress in the derivation and growth of undifferentiated hES cells and their differentiated progeny, and the problems associated with these techniques. We also examine the potential use of the therapeutic cloning technique to derive isogenic hES cells.

Reproduction (2004) 128 259-267
\end{abstract}

\section{Background}

Embryonic stem (ES) cells are derived from the pluripotent inner cell mass (ICM) cells of the preimplantation blastocysts (reviewed in Smith 2001). The derivation process involves plating of the blastocysts on mouse embryonic fibroblasts (MEF) and expansion of the outgrowth into established ES cell lines. ES cells are capable of unlimited self-renewal by symmetric division. They are also able to divide asymmetrically giving rise to one daughter cell resembling its mother, and another daughter cell giving rise to multiple types of differentiated cells representing all primitive embryonic germ layers. The latter can be tested by injecting ES cells into immunocompromised mice to produce teratomas that contain differentiated derivatives of all three germ layers.

The first successful derivation of human ES (hES) cells was reported by Thomson et al. (1998) in which the authors isolated ICM cells plated onto mitotically inactivated MEF cells. Two years latter Reubinoff et al. (2000) confirmed that hES cells could be efficiently derived from surplus embryos demonstrating at the same time the differentiation potential of hES cells under in vitro conditions. Since then, rapid progress has been achieved and numerous studies have described the derivation of new hES cell lines including methods of growing both undifferentiated $\mathrm{hES}$ cells and their differentiated progeny. These milestones relied heavily on the gradual progress made in the previous 20 years when murine ES (mES) cells, primate ES cells and embryonic carcinoma (EC) cells derived from testicular teratocarcinomas were extensively characterised (Draper et al. 2002, Draper \& Fox 2003). The last 6 years have witnessed an exponential increase in experiments aimed at improving culture conditions (Xu et al. 2001, Amit et al. 2003), genetic manipulation (Zwaka \& Thomson 2003) and differentiation regimes to produce human cells for transplantation and drug testing (Assady et al. 2001, Kaufman et al. 2001, Zhang et al. 2001, Kehat et al. 2002, Schulz et al. 2003). However the challenge remains to produce mature, functional and pure derivatives of cell types that can be utilized for transplantation purposes. To facilitate these developments, a fuller understanding of the biology of undifferentiated cell types and genes that are important in 
the maintenance of the pluripotency of hES cells is necessesary.

Human ES cells express some of the classical markers of pluripotent cells such as OCT4, alkaline phosphatase and show high levels of telomerase activity (Thomson et al. 1998, Reubinoff et al. 2000). In spite of this, they show several morphological and behavioural differences from $\mathrm{mES}$ cells: they grow more slowly and tend to form flat rather than spherical colonies (Odorico et al. 2001, Amit \& Itskovitz-Eldor, 2002). While leukemia inhibitory factor (LIF) modulated through gp130 and JAK/STAT (Janus kinase/signal transducers and activators of transcription) pathways is sufficient to prevent undifferentiated $\mathrm{mES}$ cells from differentiating, it cannot prevent the spontaneous differentiation of hES cells (Reubinoff et al. 2000, Amit \& Itskovitz-Eldor, 2002). In contrast to mES cells, which are recognised by monoclonal antibodies raised to stagespecific embryonic antigen 1 (SSEA-1), hES cells and ICM cells are recognised by monoclonal antibodies raised to SSEA-3 and SSEA-4 (Henderson et al. 2002). A set of antibodies raised to hEC cell antigens, TRA-1-60, TRA-1-81, GCTM-2, TG-30 and TG-343, that are associated with a pericellular matrix keratin sulphate/chondroitin sulphate also recognise $\mathrm{hES}$ and $\mathrm{hEC}$ cells but not mES cells (Laslett et al. 2003). In contrast to $\mathrm{mES}$ cells, hES cells also express CD9, Thy 1 and major histocompatibility complex class 1 (Henderson et al. 2002). These differences between $\mathrm{mES}$ and $\mathrm{hES}$ cells suggest that although some of the pluripotentiality genes are expressed in both $\mathrm{mES}$ and hES cells their function and downstream signalling pathways may differ. This highlights the importance of studying stem cell biology in humans given the relevance of stem cell applications in theraupetic medicine.

The capacity of hES cells to differentiate into almost all of the cell types of the human body highlights their potentially promising role in cell replacement therapies for the treatment of human diseases. Unfortunately, there are several hurdles to be overcome before such potential may be realised. For instance, the processes of ICM isolation, and in vitro culture of hES cells requires that human embryos and cells derived from them are in contact with animal ingredients or feeder cells. Large-scale culture of hES cells is time consuming and labour intensive, the presence of feeder cells may interfere with attempts to genetically modify the hES cells and prolonged growth in vitro may cause chromosomal aberrations.

In this review we summarise recent progress in hES cell research and we also highlight several problems associated with the derivation and growth of hES cells.

\section{What is important for the derivation of hES cells?}

Sufficient numbers of donated embryos and an in vitro culture system that allows development of early embryos into blastocysts with well-formed ICMs are crucial factors in the successful derivation of hES cells. To date, the majority of described hES cell lines were derived from day 5 to day 8 blastocysts produced for clinical purposes after in vitro fertilisation (IVF) or intracytoplasmic sperm injection. Meanwhile, one hES cell line has been derived from blastocysts developed from embryos reconstructed using a somatic cell nuclear transfer (SCNT) technique (Hwang et al. 2004).

The very first study that describes successful separation of human ICM cells and their continued culture for at least two passages in vitro was published by Bongso and co-workers (1994). The authors demonstrated that separated ICM cells either differentiate or produce cells with typical hES-cell-like morphology positive for alkaline phosphatase staining and with normal karyotype. This mechanical isolation of ICM has been substituted by the removal of trophectoderm (TE) cells by immunosurgery using specific antibodies raised either against BeWo cells (Thomson et al. 1998, Lanzendorf et al. 2001), or whole human serum (Reubinoff et al. 2000, Park et al. 2003, Pickering et al. 2003, Hwang et al. 2004, Stojkovic et al. 2004) or red blood cells (Cowan et al. 2004). Nearly all described hES cell lines have been efficiently derived using the immunosurgery procedure, however mechanical isolation is advantageous since there is no contact of blastocysts with animal antibodies. On the other hand, there is a risk that not all of the TE cells may be removed during mechanical isolation and these may subsequently overgrow and inhibit the growth of ICM cells (Pickering et al. 2003).

Published data suggest that the success rate in deriving $\mathrm{hES}$ cell lines is highly dependent on the quality of recovered blastocysts, isolation conditions and experience of the group (Pera et al. 2000, Mitalipova et al. 2003): Thomson et al. (1998) used 14 blastocysts to derive 5 hES cell lines; Reubinoff et al. (2000) derived $2 \mathrm{hES}$ cell lines from 4 blastocysts; Lanzendorf et al. (2001) derived 3 hES cell lines from 40 blastocysts; Park et al. (2003) derived 3 hES cell lines from 13 isolated ICMs; Pickering et al. (2003) derived $3 \mathrm{hES}$ cell lines from 58 embryos; Mitalipova et al. (2003) derived 4 hES cell lines from 19 embryos; we (Stojkovic et al. 2004) derived 1 hES cell line from 7 blastocysts; and previously Cowan et al. (2004) described the derivation of $17 \mathrm{hES}$ cell lines from 97 isolated ICMs (in total 286 early embryos and 58 blastocysts). These data are very encouraging since human IVF embryos have revealed an unexpectedly high incidence of postzygotic chromosomal abnormalities which reduce the quality of recovered embryos and contribute to early pregnancy loss after embryo transfer (Delhanty \& Handyside 1995, Trounson \& Bongso 1996, Handyside \& Delhanty 1997, Munne 2002). Surprisingly, it has been demonstrated that even aneuploid zygotes can be used as a source for derivation of hES cells (Suss-Toby et al. 2004) that could be used for research purposes.

An exact comparison of the success rate between different groups is difficult to make since some of the groups report the numbers of donated embryos and other groups 
report the numbers of blastocysts used. In addition some of the groups have used a small number of donated embryos/blastocysts from which it is difficult to extract complete data. There is also a problem of publication bias, where many groups have either used many embryos but failed to generate any hES cell lines or after successful derivation their data were not deemed sufficiently innovative and were therefore not published. However, a common factor in nearly all studies which describe successful derivation of $\mathrm{hES}$ cells is that the blastocysts used for immunosurgery are recovered in sequential two-step culture system using G1 and G2 media; this system is designed not only to allow for changes in nutrient requirements and metabolism as development of early human embryos proceeds but also to facilitate the development of highly viable blastocysts (Gardner \& Lane 2003, Gardner et al. 2004).

We successfully derived and fully characterised one hES cell line (hES-NCL1) from day 8 blastocysts recovered in a more complex three-step in vitro culture system (Stojkovic et al. 2004). Based on the sequential culture of human embryos (Gardner \& Lane 2003), this includes culture of early stages until day 3 in G1 medium, until day 6 in G2.3 medium and then culture of recovered day 6 blastocysts in medium conditioned by buffalo rat liver cells (BRL-medium). Using this protocol, all day 6 blastocysts expanded or hatched on Day 8 demonstrating that the addition of the third step is effective in supporting the hatching and growth of the blastocysts. In addition, day 8 blastocysts possess significantly more ICM cells $(\sim 50)$ than their day 6 counterparts $(\sim 30$ ICM cells; Fig. 1$)$ which is probably due to the presence of hyaluronic acid (HA) in the second step and different growth factors such as LIF, insulin-like growth factor-II (IGF-II), and transforming growth factor $\beta$ (TGF $\beta$ ) in BRL-medium (Stojkovic

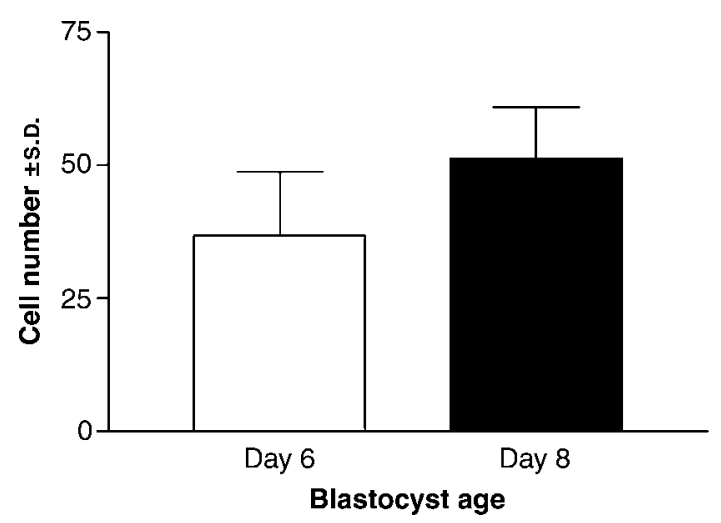

Figure 1 Numbers of ICM cells in day $6(\mathrm{IVF}=$ day 0$)$ and day 8 human blastocysts. Day 6 blastocysts were recovered after two-step in vitro culture and day 8 after three-step in vitro culture: until day 3 early embryos were cultured in G1 medium, until day 6 in G2.3 medium and then recovered day 6 blastocysts were cultured for an additional 2 days in medium conditioned by buffalo rat liver cells. The cell numbers of 11 ICMs isolated from day 6 blastocysts were compared with the cell numbers of 13 ICMs isolated from day 8 blastocysts. $P<0.05$ (Wilcoxon rank-sum test). et al. 1995). HA plays a very important role in early embryogenesis (Stojkovic et al. 2003) and, when added to culture medium, $\mathrm{HA}$ increases the cell number of mouse (Gardner et al. 1999, Figueiredo et al. 2002) and bovine blastocysts (Stojkovic et al. 2002). Added to serum-free medium, LIF increases the blastocyst rate, hatching rate and cell number of mammalian preimplantation embryos (Fry 1992, Dunglison et al. 1996) but whether greater numbers of ICM cells in day 8 blastocysts allow more-efficient derivation of hES cells is difficult to say. When plated on feeder cells, hES clumps with 50-100 hES cells have more chances to attach and proliferate than smaller cell clumps (Reubinoff et al. 2000), and for successful derivation of hES cells the ICM has to be placed on feeders as a cell clump not as single cells since ICM cells are held together tightly with numerous junctional complexes (Fong et al. 2001). Therefore, we believe that the third step could be beneficial in the derivation of hES cells since it allows further proliferation of ICM cells within the blastocyst and allows the ICM cells a further 2 days to adapt to the culture conditions they will be subject to after isolation.

\section{Growth of undifferentiated hES cells}

Continuous culture of isolated ICM cells and hES cells in an undifferentiated state still requires the presence of feeder layers. Previously described feeder or feeder-free systems including MEF, STO, foetal muscle, skin and foreskin cells, adult Fallopian tube epithelial cells (Richards et al. 2002, 2003, Amit et al. 2003, Hovatta et al. 2003, Park et al. 2003), adult marrow cells (Cheng et al. 2003), or dishes coated with animal-based ingredients with the addition of MEF-cell-conditioned medium (Xu et al. 2001, Rosler et al. 2004). Such systems are not optimal for the derivation and growth of clinical-grade $\mathrm{hES}$ cell lines since they bear a risk of cross-transfer of different infectious agents. In addition, there are reports that describe high differentiation rates of hES cells and genomic instability of hES cells after prolonged in vitro growth (Amit et al. 2003, Carpenter et al. 2004). For instance, some hES cell lines display a certain level of aneuploidy (Carpenter et al. 2004) including the gain of chromosome 17q (Draper et al. 2004), trisomy 20 (Rosler et al. 2004) or aberrant $X$ chromosome (Inzunza et al. 2004). Statistically significant differences in SSEA-4 expression, some differences in telomere length, downregulation of collagen, STAT4, a lectin and two genes involved in TGF $\beta$ signalling has been described in different $\mathrm{hES}$ cell lines derived in the same laboratory and cultured under feeder-free conditions (Carpenter et al. 2004, Rosler et al. 2004). This suggests that applied feeders and feeder-free systems for growth of undifferentiated hES cell lines are suboptimal since hES cell lines show subtle differences in gene expression upon long-term culture (Rosler et al. 2004). 


\section{Characterisation of $h E S$ cell lines}

Following successful attachment of the ICM to the feeder cell to form a primary hES colony (Fig. 2), mechanical or enzymatic disaggregation may be performed to produce further hES colonies. This first step is followed by timeconsuming and labour-intensive propagation, cryopreservation and characterisation of the new hES line. Fully characterised hES cell lines are those that show typical stem cell markers (Fig. 3), express high levels of telomerase activity, show normal karyotype and differentiation potential under in vitro and in vivo conditions and preferably have been shown to maintain these characteristics over extended periods of culture. Many new hES lines are

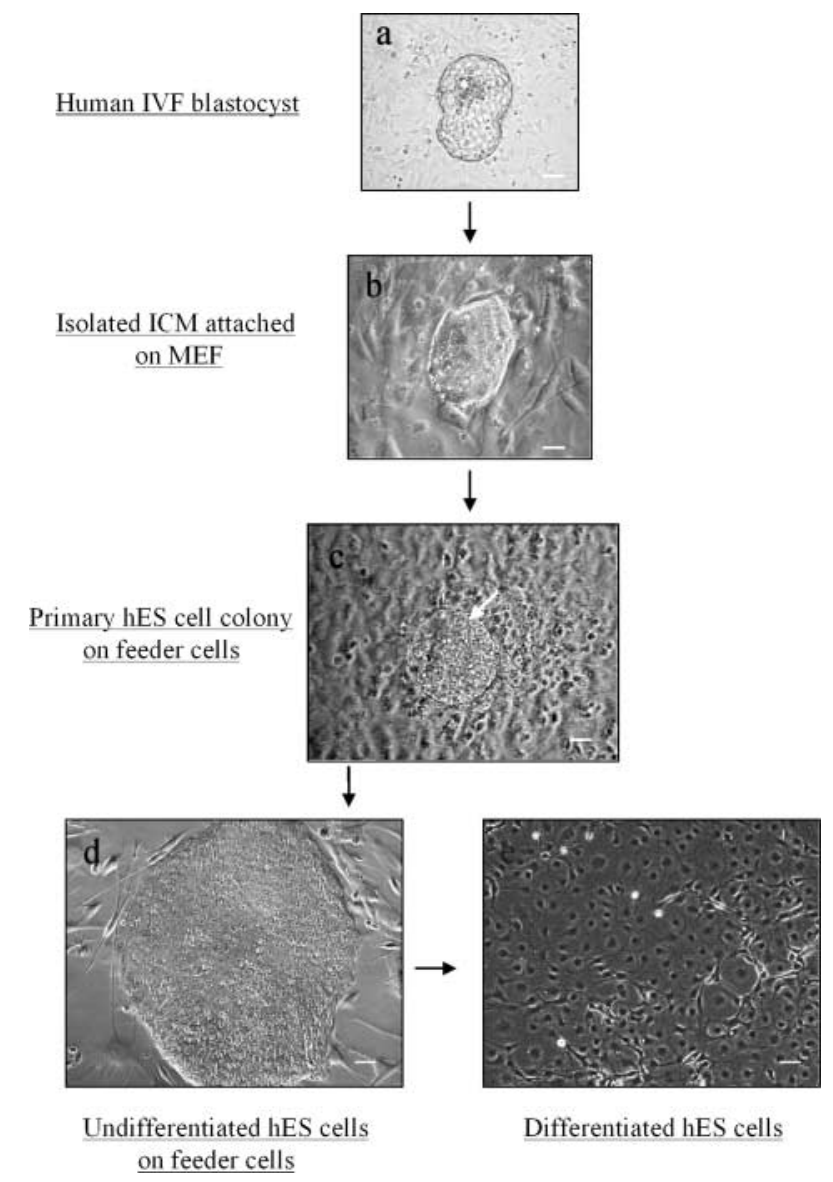

Figure 2 Derivation of hES cells. (a) Day 8 (IVF = day 0) hatching blastocyst derived after in vitro fertilisation. Alternatively, blastocysts could be received after intracytoplasmic sperm injection or nuclear transfer procedure. Note the presence of well-formed ICM (asterisk). (b) ICM isolated by immunosurgery and attached to the mouse feeder cells (MEF). Mechanical isolation of ICM is another possibility in order to remove trophectoderm cells. (c) Thirteen-day-old primary hES cell colony grown on MEF. Alternatively, feeder cells could also be of human origin. Note the presence of cells with typical hES-celllike morphology (white arrow). (d) Undifferentiated hES-NCL1 colony grown on human feeder. (e) Spontaneous differentiation of hES-NCL1 cells with neuronal-precursors morphology. Induced differentiation of pluripotent hES cells could be achieved after addition of specific factor(s). Scale bars: $200 \mu \mathrm{m}$ (a, c, d, e) and $100 \mu \mathrm{m}$ (b). described without complete characterisation, for example, formation of teratoma after injection into severe combined immunodeficient (SCID) mice and demonstration of karyotypic stability after long-term growth are often omitted. Some characterisation work with limited numbers of markers has been performed on 26 of the 60 or so reported hES cell lines (Carpenter et al. 2004) but to date it is not known how many hES cell lines exist in laboratories throughout the world (Gearhart 2004). To our knowledge there are probably more than $120 \mathrm{hES}$ cell lines worldwide, 78 of which have been included in the National Institutes of Health $(\mathrm{NIH})$ registry but not all of them are fully characterised and available to public institutions (for more information see www.stemcells.nih.gov/registry). Unfortunately, numerous newly derived hES cell lines are stored at early passage and are not fully characterised due to lack of resources.

It is important to note that not even fully characterised hES cell lines demonstrate comparable expression of cell surface (SSEA3, SSEA4, TRA1-60, TRA1-81, GTCM2, TGT343) and intracellular markers (Nanog, OCT4, Rex1), and not all hES cell lines have the same genetic profile even when cultured under the same conditions (Rosler et al. 2004). Comparing three different hES cell lines it was found that $52 \%$ of genes examined were expressed in all three independently derived hES cell lines and the expression of $48 \%$ genes was limited to just one or two hES cell lines (Abeyta et al. 2004). In addition, not all derived hES cell lines maintain their pluripotency under the same conditions, their potential for large-scale culture and growth under feeder-free protocols, or their ability to form teratomas after injection into SCID mice. Moreover, their capacity to differentiate spontaneously into different cell types under in vitro conditions (Richards et al. 2002) is variable. To our knowledge there is no study which describes the epigenetic status and stability of different hES cell lines or even one hES cell line after long-term culture. This is very important since early development and specific tissue characteristics are epigenetically regulated (Dean et al. 2001), every hES cell line possesses a unique expression signature, and it is of concern that application of genetically and epigenetically unstable hES cells in transplantation therapies could be detrimental.

Taken together, these data make it very difficult to evaluate the real number of derived hES cell lines and their authentic profiles. Therefore, complete characterisation of the hES cell lines - including their molecular status ('stemness') - and continuous genetic, epigenetic and chromosomal analysis of hES cell lines during prolonged in vitro growth are important steps. One possible solution to this cumulative problem is the establishment of national or international hES cell banks which would allow equal and detailed characterisation of deposited hES cell lines and provide scientists with all necessary information to choose the most suitable hES cell line for their own research. 


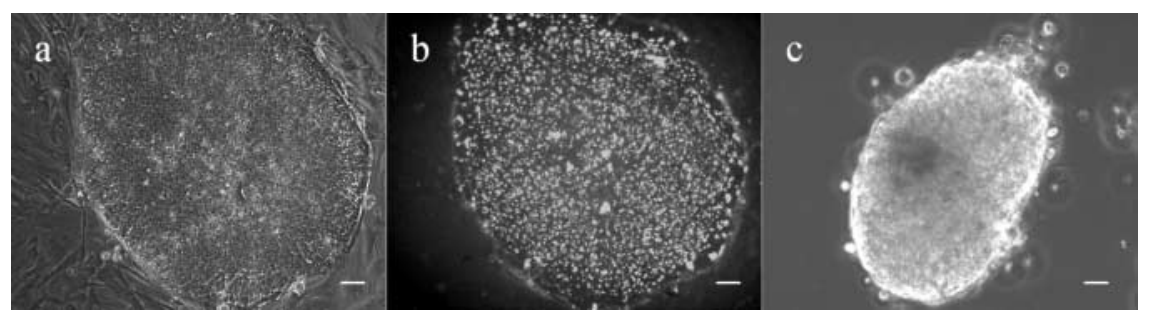

Figure 3 Human ES cells: (a) grown on mouse feeder cells; (b) stained with specific cell-surface marker (TRA1-60). When hES cells are transferred to non-adherent culture plates, they spontaneously form differentiated structures termed embryoid bodies (c). Embryoid bodies possess cells of all three germ layers and are frequently used to isolate differentiated cells under in vitro conditions. In vivo, differentiated cells could be isolated from teratomas formed after injection of hES cells into severe combined immunodeficient mice. Scale bars: $200 \mu \mathrm{m}$.

\section{Improvement of conditions for growth of hES cells and their induced differentiation}

It is not only the use of animal feeders and/or ingredients for growth of hES cells that limits the large-scale culture and medical applicability of hES cells. An additional obstacle is the slow population-doubling time of hES cells $(\sim 36 \mathrm{~h})$. In comparison, mES cells have $\sim 12 \mathrm{~h}$ population-doubling time (Amit et al. 2000) and the growth of $\mathrm{mES}$ cells under feeder-free conditions is straightforward in the presence of LIF or LIF-related cytokines (reviewed in Ginis et al. 2004). Again, hES cells do not appear to require LIF for their propagation and for maintenance of pluripotency (Thomson et al. 1998), thus identification of growth factors and components of extracellular matrix (ECM) which allow undifferentiated proliferation of hES cells under feeder-free conditions would be very helpful in the establishment of defined and xenofree culture conditions. At the same time, identification of the molecular signature of undifferentiated hES cells and their differentiated progeny including ligand/receptor pairs and secreted inhibitors of different signalling pathways such as fibroblast growth factor (FGF) and/or TGF $\beta /$ bone morphogenetic protein (BMP) pathways (Sato et al. 2003) are necessary to improve conditions not only to prevent differentiation but also to induce differentiation of hES cells. This will be extremely difficult since different growth factors have unique effects on the growth of undifferentiated hES cells and their differentiation (Schuldiner et al. 2001). For instance, one of the most routinely used mitogenic and growth factor for propagation of undifferentiated hES cells is basic FGF (bFGF) which has, however, activating potential on ectodermal and mesodermal markers (Schuldiner et al. 2000) and acts as a differentiation factor for immortalised hypothalamic neurons (Park et al. 2004).

Another possibility to identify growth factors is to analyse feeder-cell-conditioned medium. Lim \& Bodnar (2002) identified 136 unique protein species such as IGFbinding protein 4, pigment epithelium-derived factor, SPARC (secreted protein, acidic and rich in cysteine), nidogen-2, galectin 1 and peroxiredoxins from analyses of conditioned medium from MEF cells, and the STO cell line. Some of the identified proteins are known to participate in cell growth and differentiation, ECM formation and remodelling. This is one step further but more studies are necessary to investigate the proteome of hES cells and different feeders since STO cells do not produce sufficient amounts of soluble factors for selfrenewal of hES cells growing without direct contact with STO cells (Park et al. 2003).

Another possibility to keep the hES cell undifferentiated or to direct hES cells along a specified lineage is genetic manipulation, i.e. transfection of hES cells or use of small interfering RNAs (siRNAs). It has been reported that the transfection efficiency of primate ES cells is lower than that of mES cells (Furuya et al. 2003). However, hypoxanthine phosphoribosyltransferase-1 and OCT4 genes were successfully targeted by homologous recombination (Zwaka \& Thomson 2003) and the siRNAs technique was effective at knocking down gene expression (Vallier et al. 2004) in hES cells. Using homologous recombination in the cultured hES cells, specific gene defects could be repaired and, following differentiation into the appropriate tissue, hES cells would then be transplanted back to the patient (Rhind et al. 2003). Together with therapeutic cloning this offers exciting possibilities for deriving new modified and patient-friendly hES cell lines.

\section{Therapeutic cloning}

Undifferentiated hES cells express only low levels of molecules which activate an immune response. During differentiation, one of these molecules (major histocompatibility complex 1 ) is up-regulated (for review see Drukker \& Benvenisty 2004). Therefore, the application of hES cell derivatives in regenerative medicine could be harmful due to the non-self proteins expressed on the grafted cells which may result in immune rejection of the graft in the absence of immunosuppressive therapy. A potential way of avoiding this disadvantage is therapeutic cloning (TC). The objective of this technique is to produce pluripotent hES cells that carry the nuclear genome of the patient and then induce them to differentiate into cells which may be transplanted back into the patient (Rhind et al. 2003). The SCNT technique requires the introduction of a nucleus 
from an adult donor cell into an enucleated oocyte to generate a nuclear transfer (NT) embryo (Fig. 4). In culture, NT blastocysts can give rise to NT hES cells that have the potential to become almost any type of cell present in the adult body. This strategy could be used for derivation of isogenic or 'tailor-made' hES cells since all nuclear genes would be recognised as from the same origin (Hochedlinger \& Jaenisch 2003). In animals, transplantation of cells derived using the TC technique has been successfully applied in parkinsonian mice (Barberi et al. 2003) and in humans TC might substantially improve the treatment of many incurable diseases (Alzheimer's, Parkinson's,
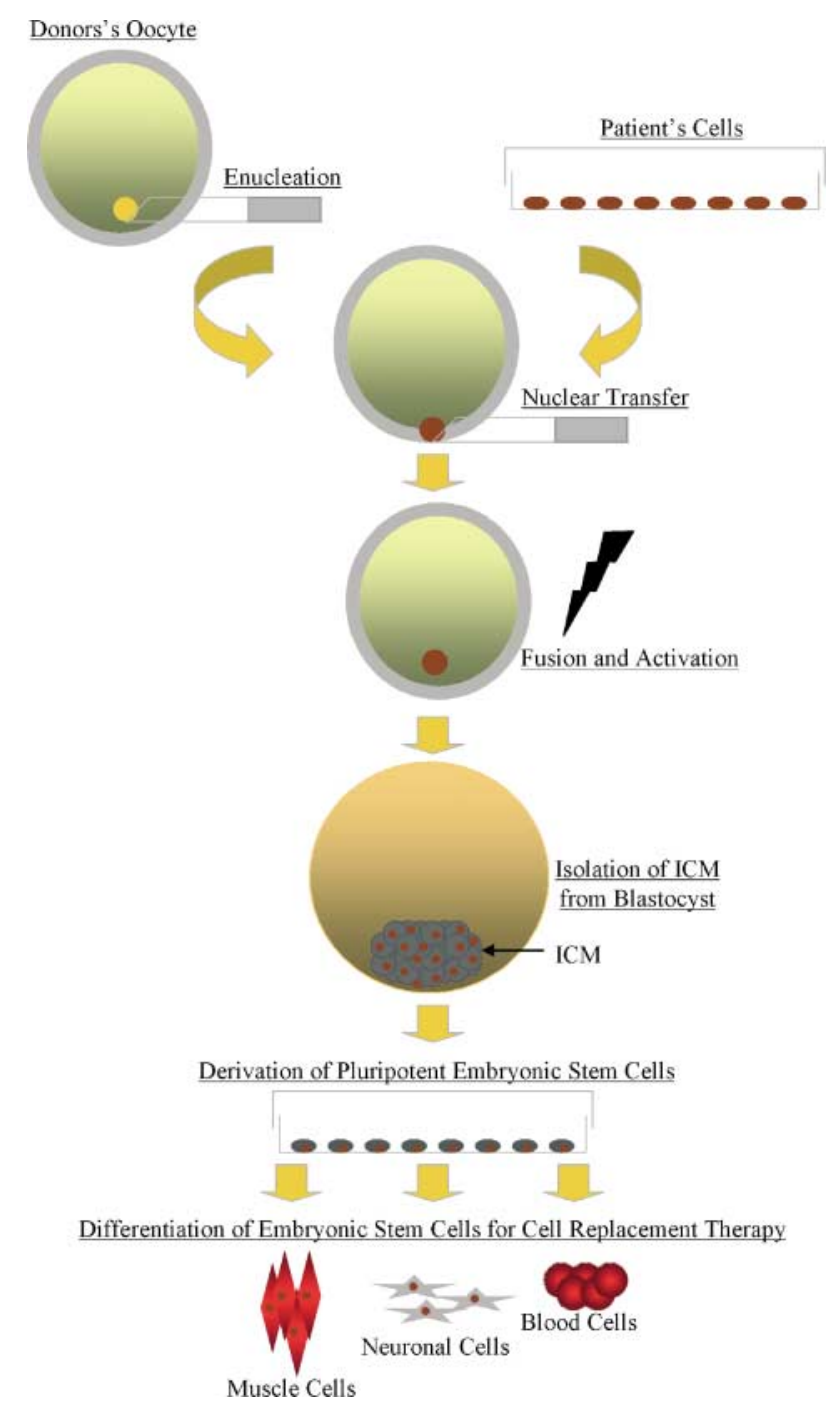

Figure 4 Steps of the therapeutic cloning technique. The nucleus of a donor's unfertilised oocyte is removed (enucleation) and replaced with the nucleus of a patient's own cells (nuclear transfer). After activation, the oocyte starts to cleave and derived NT blastocysts could be used for derivation of hES cells that have the potential to become almost any type of cell present in the adult body. This strategy offers an end to the use of immunosuppressive therapy in cell transplantation since all nuclear genes of differentiated hES cells would be recognised as having the same origin. diabetes) since therapy for these diseases is currently limited by the availability or immunocompatibility of tissue transplants. In addition, NT hES cell lines could be useful in the development of in vitro human disease models for basic research, drug discovery and toxicology. Drug researchers use stem cells as a new resource for investigating the mechanism of action of new target compounds and assessing their safety (Street et al. 2003). Furthermore, derived NT embryos and NT hES cells offer an excellent opportunity to study: the effect of oocyte-derived mitochondrial proteins in somatic cells obtained by NT; the role of mitochondrial DNA; and cell reprogramming on the genetic and epigenetic status of derived NT hES cells.

Some scientists argued that primate embryos could never undergo successful SCNT, since meiotic spindle removal from recipient oocytes, which occurs during oocyte enucleation, appears to prevent embryo reconstruction (Simerly et al. 2003). However, the previous success of Korean scientists who were able to derive the first NT hES cell line (Hwang et al. 2004) demonstrates that the major obstacles in the derivation of NT-derived hES cells are indeed of a technical and logistic nature, i.e. low numbers of high-quality donated oocytes (Birmingham 2003).

\section{Differentiation ability of hES cells}

Human ES cells have the potential to differentiate into nearly all cell types of the human body. In vitro they are able to generate embryoid bodies (structures with three germ layers formed by pluripotent hES cells grown in three-dimensional culture, Fig. 3) which express marker genes of all three germ layers and for different cell types (Schuldiner et al. 2000). Human ES cells have the ability to differentiate into neuronal, skin, adrenal and keratinocyte (Reubinoff et al. 2000, Zhang et al. 2001, Green et al. 2003), blood, endothelial, kidney, bone, mucle, heart (Kaufman et al. 2001, Kehat et al. 2002, 2003, Levenberg et al. 2002, Xu et al. 2002, He et al. 2003), pancreas and liver cells (Schuldiner et al. 2000, Assady et al. 2001; reviewed in Eiges \& Benvenisty, 2002). Induced differentiation of hES cells into cardiomyocytes which are electrophysiologically comparable with normal human cardiomyocytes and foetal ventricular myocytes has been reported by Mummery et al. (2003) and induced neuronal cell differentiation of hES cells has been achieved using retinoic acid and nerve growth factor (Schuldiner et al. 2001).

Studies in animal models show that transplantation of ES-derived cells can successfully treat a variety of chronic diseases including cardiovascular diseases, diabetes or traumatic spinal cord injury (reviewed in Odorico et al. 2001, Gerecht-Nir \& Itskovitz-Eldor 2004, Shamblott \& Clark 2004) which again underlines the promising role of hES cells in tissue regeneration and modern medicine. 


\section{Conclusions}

Derivation of hES cell lines is time-consuming and labour-intensive work. However, derivation of a new generation of clinical-grade hES cell lines is more than necessary; it requires not only in vitro production of blastocysts cultured in defined systems, isolation of ICM cells using human antibodies or mechanical methods, growth of hES cells in culture systems which contain non-compromising and patient-friendly feeder or recombinantbased media ingredients, but also unique legislation. In the European Union this will lead to the necessary upgrading of IVF and stem cell units since the European Parliament adopted a directive (2004/23/EC) setting high quality and safety standards for human tissues and cells used in therapy. The directive sets out quality requirements related to the donation, procurement and testing of tissues and cells including oocytes, sperm and hES cells (for more information see http://europa.eu.int/eur-lex/en/). After derivation, new hES cell lines should be investigated frequently for possible chromosomal aberrations, genetic/epigenetic profile after prolonged growth and the ability to differentiate.

Certainly, application of hES cells for therapeutic purposes is still premature; however, the results achieved in hES cell research during the last few years, including derivation of new hES cell lines using SCNT, demonstrate rapid progress and the increased importance of hES cells in both basic research and the long-term future of modern medicine.

\section{Acknowledgements}

The authors thank Mrs Petra Stojkovic, and Drs Mary Herbert and Lyle Armstrong for their help. This work was supported by Newcastle University Hospitals Special Trustees, One NorthEast Regional Development Agency, Newcastle Health Charity, the Department of Health and the Medical Research Council, UK (GO301182, grant 68740).

\section{References}

Abeyta MJ, Clark AT, Rodriguez RT, Bodnar MS, Pera RA \& Firpo MT 2004 Unique gene expression signatures of independently-derived human embryonic stem cell lines. Human Molecular Genetics 3 601-608.

Amit M \& Itskovitz-Eldor J 2002 Derivation and spontaneous differentiation of human embryonic stem cells. Journal of Anatomy $\mathbf{2 0 0}$ 225-232.

Amit M, Carpenter MK, Inokuma MS, Chiu CP, Harris CP, Waknitz MA, Itskovits-Eldor J \& Thomson JA 2000 Clonally derived human embryonic stem cell lines maintain pluripotency and proliferative potential for prolonged periods of culture. Developmental Biology $227271-278$.

Amit M, Margulets V, Segev H, Shariki K, Laevsky I, Coleman R \& Itskovitz-Eldor J 2003 Human feeder layers for human embryonic stem cells. Biology of Reproduction 68 2150-2156.

Assady S, Maor G, Amit M, Itskovitz-Eldor J, Skorecki KL \& Tzukerman M 2001 Insulin production by human embryonic stem cells. Diabetes 50 1691-1697.
Barberi T, Klivenyi $\mathbf{P}$, Calingasan NY, Lee $\mathbf{H}$, Kawamata $\mathbf{H}$, Loonam K, Perrier AL, Bruses J, Rubio ME, Topf N, Tabar V, Harrison NL, Beal MF, Moore MA \& Studer L 2003 Neural subtype specification of fertilization and nuclear transfer embryonic stem cells and application in parkinsonian mice. Nature Biotechnology 21 1200-1207.

Birmingham K 2003 The move to preserve therapeutic cloning. Journal of Clinical Investigation 112 1600-1601.

Bongso A, Fong CY, Ng SC \& Ratnam S 1994 Isolation and culture of inner cell mass cells from human blastocysts. Human Reproduction 9 2110-2117.

Carpenter MK, Rosler ES, Fisk GJ, Brandenberger R, Ares X, Miura T, Lucero M \& Rao MS 2004 Properties of four human embryonic stem cell lines maintained in a feeder-free culture system. Developmental Dynamics 229 243-258.

Cheng L, Hammond H, Ye Z, Zhan X \& Dravid G 2003 Human adult marrow cells support prolonged expansion of human embryonic stem cells in culture. Stem Cells 21 131-142.

Cowan CA, Klimanskaya I, McMahon J, Atienza J, Witmyer J, Zucker JP, Wang S, Morton CC, McMahon AP, Powers D \& Melton DA 2004 Derivation of embryonic stem-cell lines from human blastocysts. New England Journal of Medicine 35013 $1353-1356$.

Dean W, Santos F, Stojkovic M, Zakhartchenko V, Walter J, Wolf E \& Reik W 2001 Conservation of methylation reprogramming in mammalian embryos: aberrant reprogramming in cloned embryos. PNAS 98 13734-13738.

Delhanty JD \& Handyside AH 1995 The origin of genetic defects in the human and their detection in the preimplantation embryo. Human Reproduction Update 1 201-215.

Draper JS \& Fox V 2003 Human embryonic stem cells: multilineage differentiation and mechanisms of self-renewal. Archives of Medical Research 34 558-564.

Draper JS, Pigott C, Thomson JA \& Andrews PW 2002 Surface antigens of human embryonic stem cells: changes upon differentiation in culture. Journal of Anatomy 200 249-258.

Draper JS, Smith K, Gokhale P, Moore HD, Maltby E, Johnson J, Meisner L, Zwaka TP, Thomson JA \& Andrews PW 2004 Recurrent gain of chromosomes $17 q$ and 12 in cultured human embryonic stem cells. Nature Biotechnology 22 53-54.

Drukker M \& Benvenisty N 2004 The immunogenicity of human embryonic stem-derived cells. Trends in Biotechnology 22 136-141.

Dunglison GF, Barlow DH \& Sargent IL 1996 Leukaemia inhibitory factor significantly enhances the blastocyst formation rates of human embryos cultured in serum-free medium. Human Reproduction 11 191-196.

Eiges R \& Benvenisty N 2002 A molecular view on pluripotent stem cells. FEBS Letters $\mathbf{5 2 9} 135-141$.

Figueiredo F, Jones GM, Thouas GA \& Trounson AO 2002 The effect of extracellular matrix molecules on mouse preimplantation embryo development in vitro. Reproduction, Fertility and Development 14 443-451.

Fong CY, Bongso A, Sathananthan H, Ho J \& Ng SC 2001 Ultrastructural observations of enzymatically treated human blastocysts: zona-free blastocyst transfer and rescue of blastocysts with hatching difficulties. Human Reproduction 16 540-546.

Fry RC 1992 The effect of leukaemia inhibitory factor (LIF) on embryogenesis. Reproduction, Fertility and Development $\mathbf{4}$ 449-458.

Furuya M, Yasuchika K, Mizutani K, Yoshimura Y, Nakatsuji N \& Suemori H 2003 Electroporation of cynomolgus monkey embryonic stem cells. Genesis 37 180-187.

Gardner DK \& Lane M 2003 Towards a single embryo transfer. Reproductive BioMedicine Online 6 470-481.

Gardner DK, Rodriegez-Martinez H \& Lane M 1999 Fetal development after transfer is increased by replacing protein with the glycosaminoglycan hyaluronan for mouse embryo culture and transfer. Human Reproduction 14 2575-2580. 
Gardner DK, Surrey E, Minjarez D, Leitz A, Stevens J \& Schoolcraft WB 2004 Single blastocyst transfer: a prospective randomized trial. Fertility and Sterility 81 551-555.

Gearhart J 2004 New human embryonic stem cell lines - more is better. New England Journal of Medicine 350 1275-1276.

Gerecht-Nir S \& Itskovitz-Eldor J 2004 Human embryonic stem cells: a potential source for cellular therapy. American Journal of Transplantation 4 51-57.

Ginis I, Luo Y, Miura T, Thies S, Brandenberger R, Gerecht-Nir S, Amit M, Hoke A, Carpenter MK, Itskovitz-Eldor J \& Rao MS 2004 Differences between human and mouse embryonic stem cells. Developmental Biology 15 360-380.

Green H, Easley K \& luchi S 2003 Marker succession during the development of keratinocytes from cultured human embryonic stem cells. PNAS 100 15625-15630.

Handyside AH \& Delhanty JD 1997 Preimplantation genetic diagnosis: strategies and surprises. Trends in Genetics 13 270-275.

He JQ, Ma Y, Lee Y, Thomson JA \& Kamp TJ 2003 Human embryonic stem cells develop into multiple types of cardiac myocytes: action potential characterization. Circulation Research 93 32-39.

Henderson JK, Draper JS, Baillie HS, Fishel S, Thomson JA, Moore H \& Andrews PW 2002 Preimplantation human embryos and embryonic stem cells show comparable expression of stagespecific embryonic antigens. Stem Cells 20 329-337.

Hochedlinger K \& Jaenisch R 2003 Nuclear transplantation, embryonic stem cells, and the potential for cell therapy. England Journal of Medicine 349 275-286.

Hovatta $\mathrm{O}$, Mikkola $\mathrm{M}$, Gertow K, Strömberg A-M, Inzunza J, Hreinsson J, Rozell B, Blennow E, Andäng $M$ \& Ährlund-Richter $L$ 2003 A culture system using foreskin fibroblasts as feeder cells allows production of human embryonic stem cells. Human Reproduction 18 1404-1409.

Hwang WS, Ryu YJ, Park JH, Park ES, Lee EG, Koo JM, Jeon HY, Lee BC, Kang SK, Kim SJ, Ahn C, Hwang JH, Park KY, Cibelli JB \& Moon SY 2004 Evidence of a pluripotent human embryonic stem cell line derived from a cloned blastocyst. Science 303 1669-1674.

Inzunza J, Sahlen S, Holmberg K, Stromberg AM, Teerijoki $\mathbf{H}$, Blennow E, Hovatta $\mathbf{O}$ \& Malmgren H 2004 Comparative genomic hybridization and karyotyping of human embryonic stem cells reveals the occurrence of an isodicentric X chromosome after long-term cultivation. Molecular Human Reproduction 10 461-466.

Kaufman DS, Hanson ET, Lewis RL, Auerbach R \& Thomson JA 2001 Hematopoietic colony-forming cells derived from human embryonic stem cells. PNAS 98 10716-10721.

Kehat I, Gepstein A, Spira A, Itskovitz-Eldor J \& Gepstein L 2002 High-resolution electrophysiological assessment of human embryonic stem cell-derived cardiomyocytes: a novel in vitro model for the study of conduction. Circulation Research 91 659-661.

Kehat I, Amit M, Gepstein A, Huber I, Itskovitz-Eldor J \& Gepstein L 2003 Development of cardiomyocytes from human ES cells. Methods in Enzymology 365 461-473.

Lanzendorf SE, Boyd CA, Wright DL, Muasher S, Oehninger S \& Hodgen GD 2001 Use of human gametes obtained from anonymous donors for the production of human embryonic stem cell lines. Fertility and Sterility 76 132-137.

Laslett AL, Filipczyk AA \& Pera MF 2003 Characterization and culture of human embryonic stem cells. Trends in Cardiovascular Medicine 13 295-301.

Levenberg S, Golub JS, Amit M, Itskovitz-Eldor J \& Langer R 2002 Endothelial cells derived from human embryonic stem cells. PNAS $994391-4396$.

Lim JW \& Bodnar A 2002 Proteome analysis of conditioned medium from mouse embryonic fibroblast feeder layers which support the growth of human embryonic stem cells. Proteomics 2 1187-1203.

Mitalipova M, Calhoun J, Shin S, Winger D, Schulz T, Noggle S, Venable A, Lyons I, Robins A \& Stice S 2003 Human embryonic stem cell lines derived from discarded embryos. Stem Cells $\mathbf{2 1}$ $521-526$

Mummery C, Ward-van Oostwaard D, Doevendans P, Spijker R, van den Brink S, Hassink R, van der Heyden M, Opthof T, Pera $M$, de la Riviere AB, Passier R \& Tertoolen L 2003 Differentiation of human embryonic stem cells to cardiomyocytes: role of coculture with visceral endoderm-like cells. Circulation 107 2733-2740.

Munne S 2002 Preimplantation genetic diagnosis of numerical and structural chromosome abnormalities. Reproductive BioMedicine Online 4 186-196.

Odorico JS, Kaufman DS \& Thomson JA 2001 Multilineage differentiation from human embryonic stem cells. Stem Cells 19 193-204.

Park JH, Kim SJ, Oh EJ, Moon SY, Roh SI, Kim CG \& Yoon HS 2003 Establishment and maintenance of human embryonic stem cells on STO, a permanently growing cell line. Biology of Reproduction 69 2007-2014.

Park S, Lee KS, Lee YJ, Shin HA, Cho HY, Wang KC, Kim YS, Lee HT, Chung KS, Kim EY \& Lim J 2004 Generation of dopaminergic neurons in vitro from human embryonic stem cells treated with neurotrophic factors. Neuroscience Letters 359 99-103.

Pera MF, Reubinoff B \& Trounson A 2000 Human embryonic stem cells. Journal of Cell Science 113 5-10.

Pickering SJ, Braude PR, Patel M, Burns CJ, Trussler J, Bolton V \& Minger S 2003 Preimplantation genetic diagnosis as a novel source of embryos for stem cell research. Reproductive BioMedicine Online 7 353-364.

Reubinoff BE, Pera MF, Fong C-Y, Trounson A \& Bongso A 2000 Embryonic stem cell lines from human blastocysts: somatic differentiation in vitro. Nature Biotechnology 18 399-404.

Rhind SM, Taylor JE, De Sousa PA, King TJ, McGarry M \& Wilmut I 2003 Human cloning: can it be made safe? Nature Review Genetics 4 855-864.

Richards M, Fong C-Y, Chan W-K, Wong P-C \& Bongso A 2002 Human feeders support prolonged undifferentiated growth of human inner cell masses and embryonic stem cell lines. Nature Biotechnology 20 933-936.

Richards M, Tan S, Fong C-Y, Biswas A, Chan W-K \& Bongso A 2003 Comparative evaluation of various human feeders for prolonged undifferentiated growth of human embryonic stem cells. Stem Cells 21 546-556.

Rosler ES, Fisk GJ, Ares X, Irving J, Miura T, Rao MS \& Carpenter MK 2004 Long-term culture of human embryonic stem cells in feeder-free conditions. Developmental Dynamics 229 259-274.

Sato N, Sanjuan IM, Heke M, Uchida M, Naef F \& Brivanlou AH 2003 Molecular signature of human embryonic stem cells and its comparison with the mouse. Developmental Biology 260 404-413.

Schuldiner M, Yanuka O, Itskovitz-Eldor J, Melton DA \& Benvenisty N 2000 Effects of eight growth factors on the differentiation of cells derived from human embryonic stem cells. PNAS 97 11307-11312.

Schuldiner M, Eiges R, Eden A, Yanuka O, Itskovitz-Eldor J, Goldstein RS \& Benvenisty N 2001 Induced neuronal differentiation of human embryonic stem cells. Brain Research 913 201-205.

Schulz TS, Palmarini GM, Noggle SA, Weiler DA, Mitalipova MM \& Condie BG 2003 Directed neuronal differentiation of human embryonic stem cells. BMC Neuroscience 4 27-41.

Shamblott MJ \& Clark GO 2004 Cell therapies for type 1 diabetes mellitus. Expert Opinion on Biological Therapy 4 269-277.

Simerly C, Dominko T, Navara C, Payne C, Capuano S, Gosman G, Chong KY, Takahashi D, Chace C, Compton D, Hewitson L \& Schatten G 2003 Molecular correlates of primate nuclear transfer failures. Science $\mathbf{3 0 0} 297$.

Smith AG 2001 Embryo-derived stem cells: of mice and men. Annual Review of Cell and Developmental Biology 17 435-462.

Stojkovic M, Wolf E, Buttner M, Berg U, Charpigny G, Schmitt A \&c Brem G 1995 Secretion of biologically active interferon tau by in vitro-derived bovine trophoblastic tissue. Biology of Reproduction 53 1500-1507. 
Stojkovic $M$, Kölle $S$, Peinl $S$, Stojkovic $P$, Zakhartchenko $V$, Thompson JG, Wenigerkind H, Reichenbach H-D, Sinowatz F \& Wolf E 2002 Effects of high concentration of hyaluronan in culture medium on development and survival rates of fresh and frozen/thawed in vitro produced bovine embryos. Reproduction 124 $141-153$.

Stojkovic M, Krebs O, Kölle S, Prelle K, Assmann V, Zakhartchenko V, Sinowatz F \& Wolf E 2003 Developmental regulation of hyaluronan-binding protein (RHAMM/IHABP) expression in early bovine embryos. Biology of Reproduction 68 60-66.

Stojkovic M, Lako M, Stojkovic P, Stewart R, Przyborski S, Evans J, Armstrong L, Herbert M, Murdoch A \& Strachan T 2004 Derivation of human embryonic stem cells from Day 8 blastocysts recovered after three-steps in vitro culture. Stem Cells (In Press).

Street CN, Rajotte RV \& Korbutt GS 2003 Stem cells: a promising source of pancreatic islets for transplantation in type 1 diabetes. Current Topics in Developmental Biology 58 111-136.

Suss-Toby E, Gerecht-Nir S, Amit M, Manor D \& Itskovitz-Eldor J 2004 Derivation of a diploid human embryonic stem cell line from a mononuclear zygote. Human Reproduction 19 670-675.
Thomson JA, Itskovitz-Eldor J, Shapiro SS, Waknitz MA, Swiergiel JJ Marshal VS \& Jones JM 1998 Embryonic stem cell line from human blastocysts. Science $\mathbf{2 8 2} 1145-1147$.

Trounson A \& Bongso A 1996 Fertilization and development in humans. Current Topics in Developmental Biology 32 59-101.

Vallier L, Rugg-Gunn PJ, Bouhon IA, Andersson FK, Sadler AJ \& Pedersen RA 2004 Enhancing and diminishing gene function in human embryonic stem cells. Stem Cells 22 2-11.

Xu C, Inokuma MS, Denham J, Golds K, Kundu P, Gold JD \& Carpenter MK 2001 Feeder-free growth of undifferentiated human embryonic stem cells. Nature Biotechnology 19 971-974.

Xu C, Police S, Rao N \& Carpenter MK 2002 Characterization and enrichment of cardiomyocytes derived from human embryonic stem cells. Circulation Research 91 501-508.

Zhang S-C, Wernig M, Duncan ID, Brustle O \& Thomson JA 2001 In vitro differentiation of transplantable neuronal precursors from human embryonic stem cell. Nature Biotechnology 19 1129-1133.

Zwaka TP \& Thomson JA 2003 Homologous recombination in human embryonic stem cells. Nature Biotechnology 21 319-321. 